\title{
Trauma, emergencias, urgencias y cuidados críticos en tiempos de pandemia por COVID-19
}

Rubén D. Algieri*

Los cirujanos de trauma, emergencias, urgencias y cuidados críticos en el contexto de la pandemia desempeñan un papel importante. Si bien la enfermedad COVID-19 no requiere intervención de la especialidad en forma esencial, la formación en habilidades no técnicas-como el trabajo en equipo y la experiencia en el manejo del proceso de toma de decisiones, así como la gestión, preparación y respuesta hospitalaria ante catástrofes y desastres- y fundamentalmente el liderazgo hacen que, en el contexto del manejo de la complejidad emergente en este escenario, sus aptitudes resulten necesarias para configurar el equipo de trabajo.

La enfermedad COVID-19 es originada por un nuevo virus de la familia coronavirus, que puede causar muy escasos síntomas, como un resfrío, hasta enfermedades graves como el síndrome respiratorio de Oriente Medio (MERS-CoV) y el que origina el síndrome respiratorio agudo severo ( SARS-CoV).

EI SARS-CoV fue descubierto en noviembre de 2002, en Cantón, China. Luego apareció el virus SARSCoV-2 en Wuhan, Hubei, China, produciendo el primer caso el 08 de diciembre de 2019, según datos oficiales de las autoridades chinas, y originando la pandemia declarada por la Organización Mundial de la Salud (OMS) el 11 de marzo de 2020. En la Argentina había sido confirmado el primer caso el 03 de marzo de 2020, en un hombre de 43 años que arribó al país desde Milán, Italia.

Este virus presenta una gran capacidad de transmisión y, aunque la mayoría de las personas se recuperan sin necesitar tratamiento hospitalario, aproximadamente 1 de cada 5 enfermos desarrolla un cuadro grave. Es extremadamente agresivo en adultos mayores y en quienes padecen enfermedades crónicas; sin embargo, cualquiera puede contraer COVID-19 y enfermar gravemente.

Así, la alta incidencia de infección ha puesto a prueba los Sistemas de Salud a nivel mundial, desafiando las capacidades hospitalarias con número elevado de pacientes críticos en intervalos cortos de tiempo y con una severidad que no ha sido vista en los últimos 100 años, sobrecargando los Centros de Salud y específicamente las Unidades de Cuidados Intensivos (UCI) y haciendo imperiosa la necesidad de disponibilidad de Equipos de Bioseguridad para proteger a los profesionales de la salud, considerados una población altamente vulnerable. Tanto es así que varios documentos de- mostraron que muchos se han infectado y han muerto por la enfermedad. En pos de preservar la salud y la seguridad del personal que conforma la comunidad sanitaria, las actividades "no esenciales" fueron suspendidas o realizadas desde el domicilio, dada la necesidad de distanciamiento social.

La pandemia por coronavirus se ve entrelazada con la epidemia desencadenada por la enfermedad trauma (claramente desatendida en países en desarroIlo). Esta última representa la principal causa de muerte en menores de 45 años de la población mundial; se estima que aproximadamente el $10 \%$ de las muertes anuales mundiales ocurren por trauma. Si bien la OMS, entre 2012 y 2020, dispuso acciones destinadas a la prevención de la violencia, más del $90 \%$ de esas muertes se producen en países con ingresos bajos y medios en los que no suelen aplicarse suficientes medidas preventivas y cuyos sistemas de salud están menos preparados para afrontar el reto. El trauma contribuye al círculo vicioso de la pobreza y produce consecuencias económico-sociales que afectan a las personas, las comunidades y las sociedades. En los Servicios de Trauma, Emergencias y Urgencias son los cirujanos, clínicos y emergentólogos los que reciben a estos pacientes que ingresan junto a los enfermos con COVID-19, siguiendo los protocolos establecidos en el Programa "Advanced Trauma Life Support" (c) (ATLS), impartido en la Argentina desde 1989, donde está estandarizado que los profesionales que asisten a las víctimas deben usar el Equipo de Protección Personal apropiado.

Dada la concurrencia masiva de pacientes a las guardias, se han aplicado normas para la gestión de disponibilidad de camas, motivo por el cual los hospitales operan bajo algoritmos de triaje de emergencia. Se suspendieron cirugías electivas en función del aumento previsto de pacientes. Las salas se reorganizaron, ubicando separadamente a pacientes COVID-19 (+) y pacientes no COVID-19. Los casos de trauma han disminuido debido al aislamiento social obligatorio, al igual que las reservas de productos sanguíneos. Sin embargo la preocupación sanitaria es permanente, dada la eventualidad de disminuir las restricciones antes de que los recursos hospitalarios vuelvan a ser normales y recibir una afluencia de pacientes con trauma superpuestos a un número elevado de casos COVID-19(+). Este es un gran reto por lo que, en la redistribución dinámica del personal requerida por el distanciamiento social y 
los aislamientos por contagio, el equipo quirúrgico de emergencia se dispuso como una fuerza laboral disponible para servir en otras capacidades y, a la necesidad de su entrenamiento previo, se agregaron las medidas de protección personal y el empleo de dispositivos de aislamiento que tornó el trabajo más dificultoso; por ello, muchos tomaron cursos y módulos de actualización para el desarrollo de habilidades en la asistencia de pacientes con COVID-19.

El Shock Room, el quirófano y la Unidad de Cuidados Críticos han sido considerados escenarios de máxima exposición para el personal de salud que allí se desempeña, dado que algunos procedimientos que se realizan en ellos presentan, además, la posibilidad de aerosolización. Por tal razón se dispuso disminuir el número esencial de profesionales para la asistencia de pacientes, manteniendo el criterio de mayor capacidad y experiencia para liderar la atención. Además, dichos procedimientos en pacientes con sospecha o confirmación de COVID-19 (+)idealmente deben realizarse en áreas preparadas con presión negativa.

Con respecto a la sala de operaciones en la emergencia, fueron necesarios otros cambios específicos. La intubación endotraqueal es un procedimiento aerosolizante, por ello el anestesiólogo durante su realización, desde la inducción, esta solo o con el personal indispensable, y luego ingresa el equipo quirúrgico, todos con elementos de protección nivel III. La traqueotomía es otro procedimiento aerosolizante, por lo cual su indicación es motivo de gran controversia. Ocasionalmente, el aumento de secreciones en estos pacientes desencadena taponamiento de la vía aérea que requiere broncoscopia o recambio urgente del tubo, con el riesgo consecuente de diseminación viral. Llevar a cabo el procedimiento en forma electiva puede minimizar los peligros, y reemplazar una cánula es más rápido, simple y seguro. Algunos centros optaron por realizar estos procedimientos en $\mathrm{UCl}$, limitando así la interrupción de la ventilación de circuito cerrado y previniendo eventuales contaminaciones durante el traslado intrahospitalario. Además, se ha descripto un enfoque híbrido abierto/percutáneo para limitar la aerosolización, minimizar complicaciones hemorrágicas y el tiempo de broncoscopia. Los pasos se realizan bajo un dispositivo transparente, idealmente con presión negativa, desde la apertura traqueal. Otros procedimientos productores de aerosoles incluyen las endoscopias digestivas y el uso de la laparoscopia en la que se recomiendan medidas como el uso de evacuadores de humo y de neumoperitoneo, de sistemas de filtración antibacteriano/antiviral de alta eficacia (que también se utilizan en procedimientos de intubación endotraqueal y de colocación de drenaje pleural), y el uso alternativo intermedio de trampas de agua con solución de hipoclorito de sodio para la aspiración y evacuación de gases mediante sistemas cerrados.

El trauma y las emergencias quirúrgicas siguen siendo inevitables aun en el contexto de la pandemia, por lo que su manejo, resolución (conservadora o quirúrgica) y control (ambulatorio u hospitalario) deben abordarse en forma criteriosa, oportuna y sensata, sin retrasos y como potenciales COVID-19(+), optimizando recursos y preservando la salud de los pacientes y del personal sanitario.

\section{- ENGLISH VERSION}

Trauma, emergency and critical care surgeons play an important role during the pandemic. Although these surgeons are not particularly involved in COVID-19 care, their non-technical skills such as teamwork, experience in the decision-making process, hospital management, preparedness and response to disasters and catastrophes, and, their leadership skills, are necessary to cope with this complex scenario.

COVID-19 is caused by a novel coronavirus, which belongs to a family of viruses that cause illness ranging from the common cold to more severe diseases such as Middle East Respiratory Syndrome (MERS-CoV) and Severe Acute Respiratory Syndrome (SARS-CoV).

SARS-CoV was discovered in November 2002, in Canton, China, and was SARS-CoV-2 was first reported by officials in Wuhan City, Hubei, China, on December 8, 2019; on March 11, 2020, the World Health Organization (WHO) described the situation as a pandemic. In Argentina, the first case was confirmed on March 3, 2020 , in a 43-year-old man who arrived in the country from Milan, Italy.
The virus is highly contagious, and although most people recover without needing hospital treatment, about 1 out of 5 patients develop a serious condition. The disease is extremely aggressive in the elderly and in those with noncommunicable diseases; however, anyone can become infected and develop a serious form.

Thus, the high incidence of infection has tested the healthcare systems worldwide, challenging the hospital capacity with high numbers of critically ill patients in short intervals of time and with a severity that has not been seen over the past 100 years, overloading the healthcare centers and particularly the intensive care units (ICU). Therefore, it was necessary to provide biosafety equipment to protect healthcare professionals, who are considered a highly vulnerable population. Indeed, several documents have demonstrated that many of them have become infected and died from the disease. In order to preserve the health and safety of the health care workers, "non-essential" activities were 
suspended or performed from home, due to the need for social distancing.

The COVID-19 pandemic is intertwined with the epidemic triggered by trauma (a condition clearly neglected in developing countries). Trauma is the leading cause of mortality worldwide among people $<45$ years and it is estimated that approximately $10 \%$ of annual deaths worldwide are due to trauma. Between 2012 and 2020 the WHO set out actions to prevent violence; yet more than $90 \%$ of these deaths occur in low- and middle-income countries where preventive measures are often not sufficiently implemented and where the health systems are less prepared to meet the challenge. Trauma contributes to the vicious circle of poverty with economic and social consequences that affect individuals, communities and societies. In the trauma and emergency care departments, surgeons, clinicians and emergency physicians take care of these patients who are admitted together with COVID-19 patients, following the protocols established in the "Advanced Trauma Life Support" Program (C) (ATLS). This program, which is working in Argentina since 1989, has standardized that the professionals who assist the victims must use the appropriate personal protection equipment.

Given the massive attendance of patients to the emergency rooms, the hospitals have implemented standards for the management of bed availability; therefore, they are operating under emergency triage algorithms. Elective surgeries were canceled based on the expected increase in the number of patients. The hospital wards were reorganized and divided into COVID-19 and non-COVID-19 areas. Trauma cases and blood product supplies have decreased due to mandatory social isolation. However, there is a permanent concern for the health situation due to the possibility of reducing the restrictions before the hospital resources return to normal and receive a great number of trauma patients superimposed on COVID-19(+) cases. This is a major challenge as the emergency surgical team was set up as a workforce available to serve in other roles because of the dynamic redistribution of the personnel required by social distancing and isolation due to infection. Thus, work became more difficult due to the need for prior training and use of personal protection measures and isolation devices. For this reason, many emergency surgeons took updating courses and modules for developing skills in the care of COVID-19 patients.
The shock room, the operating room and the critical care unit have been considered scenarios where health care workers are exposed to the greatest risk of infection since some procedures performed in these areas are potentially sources of aerosols. For this reason, the number of professionals essential for patient care was limited, maintaining the concept that the leader should have the greatest skills and experience to provide care. In addition, such procedures on patients with suspected or confirmed COVID-19 should ideally be performed in areas prepared with negative pressure.

The emergency operating room underwent other specific changes. Endotracheal intubation is an aerosol-generating procedure, and only the anesthesiologist and the minimum required staff should be in the operating room during the procedure, after which the surgical team can enter wearing level 3 personal protection equipment. Tracheotomy is another aerosol-generating procedure, so its indication is highly controversial. Occasionally, excessive secretions in these patients cause airway tamponade that requires urgent bronchoscopy or tube replacement, with the resulting risk of viral spread. An elective procedure can minimize the risk and cannula replacement is more rapid, simple and safer. Some centers decided to perform these procedures in the ICU, thus limiting the interruption of closed-loop ventilation and preventing possible contamination during in-hospital transport. In addition, open surgical or hybrid approaches have been described to limit aerosol generation, minimizing bleeding complications and bronchoscopy time. The steps are performed using a transparent device, ideally with negative pressure since trachea is opened. Other aerosol-generating procedures include gastrointestinal endoscopies and laparoscopy. Several recommendations have been made for laparoscopy: use of smoke and gas evacuators, highly effective antibacterial/antiviral filtration systems (which are also used in endotracheal intubation and placement of pleural drains), and the use a closed system connected to a container with sodium hypochlorite solution for suction and evacuation of gases.

Trauma and surgical emergencies are still inevitable even in the context of the pandemic; therefore, their management (conservative vs. surgical approach) and control (either in an outpatient or inpatient basis) must be approached with common sense and timing, avoiding delays, considering all the patients COVID-19 positive cases, optimizing resources and preserving the health of patients and healthcare workers. 